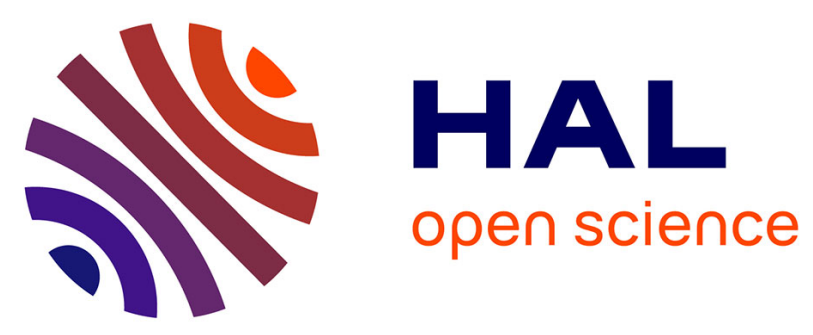

\title{
Greece between Europe and the Mediterranean, 1981-1986: The Israeli-Palestinian Conflict and the Greek-Libyan Relations as Case Studies
}

Sofia Papastamkou

\section{To cite this version:}

Sofia Papastamkou. Greece between Europe and the Mediterranean, 1981-1986: The IsraeliPalestinian Conflict and the Greek-Libyan Relations as Case Studies. Journal of European integration history, 2015, Europe and the Mediterranean in the long 1980s, 21 (1), pp.49-69. halshs-01214944

\author{
HAL Id: halshs-01214944 \\ https://shs.hal.science/halshs-01214944
}

Submitted on 13 Oct 2015

HAL is a multi-disciplinary open access archive for the deposit and dissemination of scientific research documents, whether they are published or not. The documents may come from teaching and research institutions in France or abroad, or from public or private research centers.
L'archive ouverte pluridisciplinaire HAL, est destinée au dépôt et à la diffusion de documents scientifiques de niveau recherche, publiés ou non, émanant des établissements d'enseignement et de recherche français ou étrangers, des laboratoires publics ou privés.

\section{(ㅇ)(1) $\$$}

Distributed under a Creative Commons Attribution - NonCommercial - NoDerivatives $\mid 4.0$ 
Greece between Europe and the Mediterranean, $1981-1986$.

The Israeli-Palestinian Conflict and the GreekLibyan Relations as Case Studies Sofia PAPĀSTAMKOU

Sofia PAPASTAMKOU

\begin{abstract}
This article examines aspects of the foreign policy of Greece's socialist Prime Minister Andreas Papandreou regarding the Mediterranean from 1981 to 1986. The Mediterranean was one of the three circles of Papandreou's "multidimensional" approach in foreign policy, a conceptualized one that encompassed Greece's Arab policy, mainly from a third road point of view. Two case studies are considered, the Greek-Palestinian and the Greek-Libyan connections, principally from a European perspective. Opting for a global rather than a bilateral perspective allows to fully appreciate the evolution of Greek foreign attitudes at the time mainly from the perspective of their Europeanisation.
\end{abstract}

In October 1981, Andreas Papandreou, founder and charismatic leader of the Panhellenic Socialist Movement (PASOK), brought the Socialists into power for the first time in Greece's postwar history. He was considered to be the man of change in all domains, including foreign policy. Papandreou preached a third world neutralist stance and his preelectoral speeches promised to readjust relations with the US, NATO and the EEC, of which Greece became full member that very year. This article examines the foreign policy of Papandreou regarding Mediterranean affairs from 1981 to 1986, principally from a European perspective. Opting for a global rather than a bilateral perspective allows us to better understand an essential aspect of Greek foreign attitudes at the time: their Europeanization. Moreover, from the point of view of European unification history, this approach helps to shed light on aspects of Euro-Arab relations in a period that followed the deadlock of the Euro-Arab dialogue but was yet far from the launch of the Euro-Mediterranean partnership. In parallel, from an international history point of view, the period covers the second cold War and sees the rise of the concept of war against international terrorism. It is in this context that two case studies receive special attention: the Greek-Palestinian and the Greek-Libyan connection.

\title{
The Mediterranean in Andreas Papandreou's Foreign Policy Views
}

According to Papandreou's views, Greece was part of three circles: Europe, the Balkans and the Mediterranean. These were the cores of his so-called "multidimensional policy", one that attached more importance 
to the North-South rather than to the East-West divide. ${ }^{1}$ The term "Mediterranean" was systematically used to describe relations with "the Mediterranean people", especially "the Arab Nation", instead of the terms "Orient" and "Arab World" used by his (conservative) predecessors up until then. Greece's Arab policy traditionally took into consideration dependence on the Middle East oil provisions, the geographical proximity, the presence of Greek communities and economic activity of Greek nationals in the Arab countries, the existence of three orthodox Patriarchates (Alexandria, Jerusalem and Antioch). ${ }^{2}$ The Cyprus affair and the need for Arab support in the international organizations were added to these factors from the fifties onwards. ${ }^{3}$ What seemed new in Papandreou's views was his neutralist stance and the willingness to give substance to the idea of Greece being an integral part of the Mediterranean world, in the sense of being at once a European and a developing country, because of its troubled and rich in foreign interventions post-war history, perceived as unique for a NATO and EEC member state. Notwithstanding his dominant personality, Papandreou's neutralist stance was representative of the majority of the senior party members. ${ }^{4}$

Papandreou's views on international relations and the place of Greece in the world were developed under the influence of his proper intellectual orientations and career in the USA, and his experience of the Greek political arena in the sixties. Through his studies, academic career and political action in the USA, where he lived for almost twenty years until 1959, Papandreou was linked to the liberal wing of the Democrats and to a network composed of influential personalities, such as the economists John Kenneth Galbraith and Carl Kaysen, who would later serve in the Kennedy and Johnson administrations. ${ }^{5}$ During his brief political career in Greece after 1963, he was marked by the first Cyprus crisis in 1963-64 and witnessed the exercise of international politics in the Eastern Mediterranean from within, as he was present at the US-Greek contacts in Washington regarding the crisis containment. ${ }^{6}$ As he admitted, the Cyprus crisis constituted his

1 See the founding act of the Pasok (3 September 1974 declaration) in: K. VARELA, Andreas G. Papandreou 1919-1981, Hellenika Grammata, Athens, 2002, pp.186-193; PASOK (ed.), Statement of government policy. Contract with the People, Pasok, Athens, 1981.

2 IKK [Konstantinos Karamanlis Foundation], Karamanlis Archive, document $3 A, 951$.

3 I. SAKKAS, Greece, the Cyprus Affair, and the Arab World, 19471974, Patakis, Athens, 2012, p.154.

4 Anonymous interview to the author, 22.12.2011. See also A. PAPANDREOU, Man's Freedom, Karanasis, Athens, 1974, pp.93-133; L. RORI, Analyse de l'antiaméricanisme grec: le cas du PASOK de 1974 à 2002, Mémoire de DEA inédit, IEP, Paris, 2002.

5 Papandreou studied political economy at Harvard University and eventually attained tenure in the University of California, Berkeley, where he became head of the Department of Economics in 1956. S. DRAENOS, Andreas Papandreou. The Making of a Greek Democrat and Political Maverick, I.B. Tauris, London, 2012.

6 Papandreou witnessed these contacts as Minister to the Prime Minister George Papandreou. On the 1963-64 Cyprus crisis see A. JAMES, 
political awakening in international relations and forged his views on the exercise of foreign policy from the point of view of a small state. The military Junta of 1967-1974 further radicalised his political thinking. His book Paternalistic Capitalism, published in 1972, reflects his orientation from the orthodox economist he had been until then towards the dependency theory and more radical US intelligentsia such as neo-marxist economists Paul Baran and Paul Sweezy or Richard J. Barnett, founder of the Institute for Policy Studies. ${ }^{7}$ According to his academic colleagues, the book was mainly a political manifesto that reflected the author's own experiences and the perspective of a small state. ${ }^{8}$ Indeed, Papandreou's ideas on international affairs were a mix of global conceptions nourished in the USA and his personal experiences at a local level.

One cannot consider the Mediterranean and Greece's place in it without encompassing the realities of the Greek-Turkish relationship and the problem of Cyprus, especially after the division of the island in 1974. The latter aspects, however, were distinctively considered as the Greek "national matters" in foreign affairs and defence, what has precisely been conceptualized as the core versus periphery policies. ${ }^{9}$ This article focuses on aspects of the periphery Mediterranean policies, though considering the connections with the Cyprus problem and the Greek-Turkish relations, as well as the ways in which they formed part of the Greek-US relationship.

\section{The Greek Attitude towards the Israeli- Palestinian Conflict in the EPC Framework}

The Greek-Palestinian connection is one domain where Andreas Papandreou showed a remarkable consistency. ${ }^{10}$ His support of the Palestinian Liberation Organization (PLO) was not separate from his Realpolitik concerns: it was an accessory of Greece's policy towards Turkey, as he admitted to Foreign Minister of France Claude Cheysson in 1981. ${ }^{11}$ The common ground between Greeks and Palestinians from this point of view was very likely the support the PLO provided to the Kurdistan Workers'

Keeping the Peace in the Cyprus Crisis of 1963-64, Palgrave, New York, 2002 .

7 A. PAPANDREOU, Democracy at a Gunpoint, Karanasis, Athens, 1974, pp.203-206 and A. PAPANDREOU, Paternalistic Capitalism, University of Minnessota Press, Minneapolis, 1972.

8 Reviews on Paternalistic Capitalism by K. de SCHWEINITz Jr in:

The Journal of Politics, 1 (February 1973), pp.227-229; by H.K. BETz in:

Journal of Economic Litterature, (1973), pp.556-558; in: Journal of Economic Issues, $3(1974)$, pp.617-626.

9 T. COULOUMBIS, PASOK's Foreign Policies, 1981-89: Continuity or Change?, in: R. CLOGG (ed.), Greece, 1981-89. The Populist Decade, Macmillan Press, London, 1993, pp.113-130.

10 E. STAVROU, A Pioneering Vision? Greek-Arab Relations During the Papandreou Era, 1981-1989, Papazissis, Athens, 2010, pp.135-169.

11 MAE [Ministère des affaires étrangères de France], Grèce 19811985, 5261, "Entretien avec M. Papandreou", 12 January 1982. 
Party (PKK). Indeed, after the 1980 military coup d'état in Turkey, Kurdish guerrilla forces had been installed in Lebanon where they received PLO (and Syrian) backing. ${ }^{12}$ But ideology - anti-Americanism and emotion were driving forces as well. Parallels were largely drawn by the PASOK militants between Israel and Turkey, perceived to be offered unconditional backing by the US in the Middle East. Another key determinant of their solidarity towards the Palestinians was the Cypriot experience of partition and exodus, and even the collective memory of Asia Minor Greeks exodus after $1922 .{ }^{13}$

When Papandreou came to power in 1981, the PLO already had an information office in Athens but no official recognition from the Greek government. Israel, on the other hand, had been granted only de facto recognition from Greece since 1949, although the two countries held relations through diplomatic representations. ${ }^{14}$ Right after his election, Papandreou invited Yasser Arafat to visit Greece in order to hold discussions on the upgrading of the PLO office in Athens to that of a diplomatic mission, indeed to the same level as Israel's. This was already annoying for the Israelis for prestige matters but their worries were far more general. Papandreou's invitation coincided with the launch of the second wave of the PLO's campaign for international recognition. The first one occurred from 1974 to 1979 and had been successful mainly in third world countries. In 1981, Arafat's efforts met with success not only in Greece, but also in the USSR and Japan, this second country being a temporary member of the UN Security Council at the time. ${ }^{15}$ With Greece officially joining the EEC that year, Israel worried about the country becoming the voice of the PLO in the common Western European instances.

Papandreou, who was an opponent of the Camp David accords, confirmed these apprehensions shortly after his election, when the Greek government impeded the adoption of a collective European

12 O. BENGIO, The Turkish-Israeli Relationship: Changing Ties of Middle Eastern Outsiders, Palgrave Macmillan, New York, 2004, p.137; S.A. PLAKOUDAS, The PKK and the Guerrilla Tradition of Turkey's Kurds, in: MERIA, 4(2014), <http://www.rubincenter.org/2015/02/the-pkk-and-theguerrilla-tradition-of-turkeys-kurds/> [All URL cited in this article were accessed on 4 March 2015].

13 See interviews of militants in RORI 2002, pp.111-113. For the the exodus of Asia Minor Greeks see A. JAMES, Memories of Anatolia: generating Greek refugee identity, in: Balkanologie, 1-2(2001), <http: //balkanologie.revues.org/720>.

14 Israel State Archives, http://www.archives.gov.il/, Greece's Relations with Israel, 1961-1967,

<http://www.archives.gov.il/archivegov eng/publications/electronicpirsum/gr eece/introduction1.htm>.

15 JTA [Jewish Telegraphic Agency], Archive, www.jta.org, "News Brief", 11.12.1981, <http://www.jta.org/1981/12/11/archive/palestineliberation-organization-leader-yasir-arafat-is-scheduled>; "Study Says PLO Exaggerates Its International Success", 22.12.1981, <http://www.jta.org/1981/12/22/archive/study-says-plo-exaggerates-itsinternational-success>; TNA [The National Archives], PRO FCO 9/3187, Athens to FCO, 280, 23.10.1981. M. HILL, The Emergence of the Palestinians since 1948, Part Two: The Palestinians after the creation of Israel, in: Journal of Arabic, Islamic \& Middle Eastern Studies, 1(1999), pp.45-59. 
Political Cooperation (EPC) decision on the proposed participation of the UK, France, Italy and the Netherlands in the multinational force of Sinai. ${ }^{16}$ A compromise was found by issuing a two-fold declaration. A joint one considered the decision of the four as being in accordance with the wish of the EEC to facilitate a peace settlement in the Middle East, according to the rights of all states to existence and security and the right of the Palestinians to self-determination. The second one was a common declaration between the four participating states, mentioning the Camp David Accords and the Venice Declaration. ${ }^{17}$

As for East-West relations, Greek views on Middle Eastern matters were expected to raise impediments to the adoption of common decisions because of PASOK's sympathy for the third world causes, including support for the PLO. However, Greek positions on the IsraeliPalestinian conflict were not that unique. In many ways, they were parallel to the Irish views and sometimes coincided with those of the French and the Italians. ${ }^{18}$ But as the case of the 1982 Lebanon War highlights, Greek and Irish efforts in the EEC were at best able to contribute to the adoption of severe verbal stances against the Israeli military action and reiterate basic European positions on Palestinian national rights, in accordance with the 1980 Venice Declaration, only when backed by bigger members. In particular, it was mostly France's Middle Eastern policy that produced the conditions for Greek proposals to be adopted. It would thus be interesting to see whether there was actually any substance in what was perceived to be at the time a kind of special relationship. In both countries, the socialists had come into office almost simultaneously. François Mitterrand was the first Socialist President of the Fifth Republic and Papandreou the first Socialist Prime Minister of post-war Greece. Both of them were perceived as the men of change in their respective countries. The two parties had close contacts since the mid-seventies as parts of a network of the Southern European socialist forces that developed after the fall of dictatorships in Greece, Spain and Portugal. ${ }^{19}$ These links were further tied after the extension of this network to the EuroMediterranean area following the Malta conference of $1977 .{ }^{20}$ Four days

16 TNA, PRO FCO 9/3178, Note for the file, 30.10.1981; PRO FCO 9/3189, Athens to FCO, 355, 18.11.1981; JTA Archive, www.jta.org, "Greek Objections Delay EEC Approval of Participation in Mfo", 03.11.1981, <http://www.jta.org/1981/11/03/archive/greek-objections-delay-eec-approvalof-participation-in-mfo>.

17 AEI [Archive of European Integration, <http://aei.pitt.edu/>], Statements of the Foreign Ministers and other documents. European Political Cooperation, 1981 . 18 TNA, PRO FCO 9/3189, Athens to FCO, 452, 24.12.1981; PRO FCO 9/3178, Minute [on] The Greek Elections, 21.10.1981. See also R. MILLER, Ireland and the Palestine Question 1948-2004, Irish Academic Press, Dublin, 2005.

19 Le poing et la rose, May 1977, p.27. According to one

Mitterrand's biographers, the former sought to federate the socialist powers of Southern Europe also out of will to balance the influence of the Northern European socialist parties in the Socialist International, see F.O. GIESBERT, François Mitterrand, une vie, Seuil, Paris, 1996, p.353. 20 P. AVGHeRINos, The Change Finished Early, Estia, Athens, 2013, p.56 (in Greek). 
after Papandreou's election in October, French envoys went to Athens to congratulate him on behalf of Mitterrand. When French Foreign Minister Cheysson visited Athens in December 1981, the Greek press celebrated the bond that allegedly united the two "Mediterranean, socialist and democratic" countries. According to former Minister Theodoros Pangalos, Andreas Papandreou had a special relation with Mitterrand, whom he admired, whereas the latter would keep an eye on the former because he apprehended his spontaneity - what the British called with less hesitation his "unpredictability". ${ }^{21}$

The basic foundations of France's foreign policy were essentially different from Greece's. France was more conscious of Cold War realities and, as a result, there was not much enthusiasm for Greece's neutralist views regarding the Balkans and the Mediterranean, except to the extent that this could be useful for issues of special French interest. ${ }^{22}$ In the Middle East, there were fundamental differences of approach. The French Socialists, contrary to their Greek comrades, had established contacts both with the PLO representatives in France and the Israeli socialist parties (Israeli Labour Party, Mapam, Moked). Mitterrand was a supporter of the Camp David accords and the matter of the multinational force of Sinai was clearly the object of French-Greek disagreement during Papandreou's visit to Paris in November $1981 .{ }^{23}$ Mitterrand himself was a friend of Israel yet committed to an evenhanded approach of the Israeli-Palestinian conflict, as he had plainly recognised the right of the Palestinians to self-determination since 1976. French relations with the PLO were far more complicated an issue, but Foreign Minister Cheysson publicly defended pro-Arab positions and was involved in unofficial contacts with PLO dignitaries. ${ }^{24}$ France's Arab policy and shared militant views on the North-South divide produced the conditions for considering Papandreou a potentially useful friend regarding the Mediterranean issues, in spite of basic differences of approach. On the contrary, other - Conservative ruled country members such as the UK and Belgium were far more reserved and even willing to isolate Greece in order not to allow Papandreou to weaken common EPC decisions. ${ }^{25}$

21 TNA, PRO FCO 9/3187, Athens to FCO, 280, 23.10.1981: MAE, Grèce 1981-1985, 5261, Athènes 592, 31.12.1981. See also T. PANGALOS, In Europe with Andreas, Patakis, Athens, 2011, pp.85-87 (in Greek); TNA, PRO FCO 9/3177, Minute by Wilkinson to Fergusson, 19.10.1981.

22 In the Balkans, Yugoslavia was one of them, as French were keen to support the country through a favourable EEC policy regarding the commercial balance and by providing technical assistance, see MAE, Grèce 1981-1985, 5261 Rebeyrol, Athènes 581, 31.12.1981.

23 Le poing et la rose, May 1977, p.22; Libération, 26.11.1981.

24 See R. FRANK, L'«effet Mitterrand» à I'étranger (1981-1982): un "état de grâce», un jeu de miroir et une politique extérieure de l'image, in: S. BERNSTEIN, P. MILZA, J.-L. BIANCO, François Mitterrand. Les années de changement, Perrin, Paris, 2007, pp.123-124; R. DUMAS, Affaires étrangères. 1981-1988, Fayard, Paris, 2007, pp.29-32 and 40; J.P. FILIU, Mitterrand et la Palestine, Fayard, Paris, 2005, Kindle file; New York Times, 07.07.1982.

25 TNA, PRO FCO 9/3189, Richards to FitzHerbert, 21.12 .1981$. 


\section{The 1982 Lebanon War}

On 3 June 1982, the terrorist organisation of Abu Nidal perpetrated an attack against Shlomo Argov, the Israeli Ambassador in London. Though relations between Abu Nidal and the PLO were conflictual, Israel responded by launching operation Peace for Galilee in Southern Lebanon, with the aim of expelling all Palestinian military forces from the country in an effort to secure its Northern border. ${ }^{26}$ Greece's official reaction condemned the Israeli invasion of Lebanon, repeated support for a global solution of the Israeli-Palestinian conflict following the UN Security Council resolution 242 of 1967 and the principle of the right of the Palestinians to independence, and reiterated support for the PLO as the sole representative of the Palestinian people. ${ }^{27}$ At the same time, Greece engaged diplomatic activity in the EEC. On 7 June, the day following the launch of the Israeli operation, the Greek Ministry of Foreign Affairs asked formally for an extraordinary EPC meeting to be held. Preliminary contacts were held at different levels (UN Representatives, Political Committee, Foreign Ministries' directors) and, on 9 June, the ten members of the EEC released a statement that condemned the invasion of Lebanon as a violation of international law and contrary to the efforts to achieve a peaceful settlement in the Middle East. The statement expressed support for Lebanon's territorial integrity and called for respect of UN resolutions 508 and 509 regarding an immediate withdrawal of Israeli forces from the country and UNIFIL action. It finally reiterated the European position in favour of the establishment of a global peace in the region. ${ }^{28}$

However, this common statement did not mean real convergence towards an active European approach. This became plainly evident when the Israeli operation extended beyond Southern Lebanon and France adopted a more active stance that failed to find European support. Mitterrand's first official declarations had remained balanced towards Israeli, Palestinian and Syrian action in Lebanon, but the siege of West Beirut after 13 June incited him to undertake an intense international activity in order to preserve the PLO as an interlocutor in any peace solution. Farouk Kaddoumi, the PLO political section chief, was received in Paris where he met Premier Pierre Mauroy, Foreign Minister Cheysson and Secretary General of the Socialist Party Lionel Jospin. These contacts were part of the French activity in the UN, where concerted French-Egyptian action sought to amend the UN resolution 242 to also include the Palestinian national rights. Such French activity was opposed by the USA and found limited, if any,

26 Y. MELMAN, Master Terrorist. The True Story of Abu-Nidal, Adama Books, New York, 1986; P. SEALE, Abu Nidal : A Gun for Hire, Random House, New York, 1992; H. LAURENS, La question de Palestine: 1967-1982, Fayard, Paris, 2011, pp.794-796.

27 The Greek Parliament Proceedings, 10.05-10.06.1982, p.7182 (in

Greek) .

28 MAE, CEE 1981-1985, 5004, Bruxelles COREU 2296, 07.061982;

$2315,08.06 .1982 ; 2336,09.06 .1982$. 
support among the European partners except for Greece. The Federal Republic of Germany (FRG) and the Netherlands opposed any explicit reference to the PLO in the European statements, as well as imposing serious economic sanctions on Israel. ${ }^{29}$ Furthermore, the Lebanon War was precisely the moment when British priorities shifted in favour of the Anglo-American relationship. US support to the UK during the Falklands War, the departure of Secretary of State Lord Carrington from the Foreign office and Margaret Thatcher's complete alignment with Ronald Reagan, determined the British policy direction in a way that British influence was used to limit European support to the PLO and align the EEC with the US in the Middle East. ${ }^{30}$

After Paris, Kaddoumi visited Athens where Papandreou assured him of Greece's support for the Palestinian cause. During Kaddoumi's visit, Papandreou violently condemned the Israeli military operations in Lebanon, comparing the action of the Israel Defense Forces (IDF) against the Palestinian people to Nazi crimes. The use of the legacy of the Second World War was neither new nor original in the verbal wars surrounding the Israeli-Palestinian conflict. After the 1980 Venice Declaration, the Israelis compared the PLO to the SS and Arafat to Hitler. Official PLO communication assimilated Zionism - the state of Israel not being mentioned as such - to racism and nazism since the 1970s. ${ }^{31}$ But these perceptions were further generalized during the 1982 Lebanon War and even internationalized, especially after the Sabra and Shatila massacres. The impact was felt in the Netherlands, Luxembourg, Denmark and even the FRG. So it did in France. ${ }^{32}$ But Papandreou was the first Greek Prime Minister to completely identify his views with these of one of the conflicting parties. By importing this kind of discourse into the Greek public space, at the highest level, he contributed to the tensions the Lebanon War gave rise to in the Greek society, mainly through a partial coverage of the event by the Greek media. ${ }^{33}$

What was at stake behind these diplomatic contacts and the continuing military operations in Lebanon was the evacuation of Beirut by the PLO fighters. In August, a multinational force (MNF) composed of US, French and Italian contingents arrived at the Lebanese capital in

29 A.-K. KREFT, The Weight of History: Change and Continuity in German Foreign Policy towards the Israeli-Palestinian Conflict, Master's Thesis, Western Washington University, 2010, p.50.

30 A.M. EAMES, Margaret Thatcher's Diplomacy and the 1982 Lebanon War, in: Mediterranean Quarterly, 4(2015), pp.27-44.

$31 \quad$ Christian Science Monitor, 03.09.1982

<http://www.csmonitor.com/1982/0903/090371.html>; BDIC [Bibliothèque de documentation internationale contemporaine], PLO Department of Information and Culture posters collection, 1974-1987. See also H. LAURENS, op.cit., pp. 724 and 741 .

32 I. GREILSAMMER, Reflections on the Capability of the European Community to Play an Active Role in an International Crisis: The Case of the Israeli Action in Lebanon, in: I. GREILSAMMER, J. WEILER (eds), Europe and Israel: Troubled Neighbours, de Gruyter, Berlin, p.297; J. BOURDON, Le récit impossible. Le conflit israélo-palestinien et les médias, Ina/De Boeck, Brussels, 2009 , p.100.

33 The Greek Parliament Proceedings, 15.11.1982-10.12.1982, pp.1474-1478 (in Greek). 
order to oversee the departure of the Palestinian armed forces, while the siege of Beirut West by Israeli forces continued. France had tried to associate a Greek contingent as well, as a means to attenuate soviet distrust. Papandreou was positive but no formal request was made by the Lebanese government. ${ }^{34}$ When Yasser Arafat left Beirut, aboard a Greek merchant ship, Greece was his first destination. As he declared, this was "a deliberate gesture to criticize all the Arab leaders for their stand during the Beirut siege", considering that the Greek government had been more supportive. ${ }^{35}$ Indeed, no Arab country had shown willingness to host the PLO on its soil after its departure from Lebanon. ${ }^{36}$ On the other hand, when Arafat landed in Athens on $1^{\text {st }}$ September, Mitterrand had just started a two day visit to the Greek capital. Although, according to the Greek government, this was a coincidence, the archive of Konstantinos Karamanlis, the Greek President, echoes rumours that Papandreou had tried to arrange a meeting between Arafat and Mitterrand, something the Elysée officially and publicly excluded. ${ }^{37}$

In September 1982, there was fresh diplomatic activity on the Israeli-Palestinian conflict. On $1^{\text {st }}$ September, the Reagan Plan denied support to the establishment of an independent Palestinian state and excluded permanent control or annexation by Israel. The plan called for a Jordanian-Palestinian association after a five-year transitional period of self-government in the West Bank and Gaza. Consequently, the $12^{\text {th }}$ Arab League summit issued a declaration at Fez, Morocco, on 9 September, calling for the establishment of an independent Palestinian state and recognizing the $\mathrm{PLO}$ as the sole legitimate representative of the Palestinians. ${ }^{38}$ These initiatives led to a new statement of the Ten. Its release was precipitated by the assassination of Bashir Gemayel, who was soon to take office as President of Lebanon, on 14 September, and the Sabra and Shatila massacres of civil Palestinians by Lebanese Christian militia soon after. The statement called for the immediate withdrawal of all Israeli forces from West Beirut and of all foreign military, except for the UNIFIL. It underlined the need for a global peace solution in the Middle East and the association of the PLO to all future negotiations. Recognition of Israel's right to a secure existence and the Palestinians' right to self-determination should be included, the statement said, in any peace solution. Finally, it

34 G. SHULTZ, Turmoil and Triumph, Simon and Schuster, New York, 2010, Kindle file, emplacement 994. J.P. FILIU, op.cit., emplacement 21392140 .

$35 \quad$ Christian Science Monitor, 03.09.1982

<http://www.csmonitor.com/1982/0903/090371.html>.

36 8,500 PLO fighters were evacuated to Tunisia and another 2,500 to Syria, Iraq and Yemen, whereas Egypt and Saudi Arabia refused to host any, see A. SHLAIM, The Iron Wall, Penguin Books, London, 2001, p.413. 37 KONSTANTINOS KARAMANLIS ARCHIVE (ed.), Events and Texts, vol.12, President of the Democracy 1980-1995, Ekdotiki Athinon, Athens, 1997, p.209 (in Greek).

38 Ronald Reagan Presidential Library, Address to the Nation on United States Policy for Peace in the Middle East, 01.09.1982, <http://www.reagan.utexas.edu/archives/speeches/1982/90182d.htm>; New York Times, 10.09 .1982 . 
approved the Reagan Plan and also mentioned the Fez statement as an expression of the will of its signatories, including the PLO, to work for peace in the Middle East. The statement's formulation was an outcome of Greek, Irish and French amendments of a project initially prepared by the Danish who held the EEC presidency at the time. The Greeks were eager that the Fez statement be underlined and so were the Irish, who wished to see a strong condemnation of the Israeli military occupation of West Beirut and an explicit mention of the Palestinians' right to self-determination. The Irish argument was that the common European statement should take care to leave the door open to the future participation of the PLO in any peace negotiations, especially in the light of its withdrawal from Lebanon. French backing of these proposals allowed the adoption of the final text, not least because the widespread emotion the Sabra and Shatila massacres had an impact on the attitude of all the European partners. ${ }^{39}$

\section{The Greek EEC Presidency, July-December 1983}

The first Greek presidency of the EEC occurred in the second semester of 1983. It did not lead to any major evolution of the common European position regarding the Middle East matters. The EEC countries opted for a low profile during an international conference on the Palestinian question, held during the summer in Geneva, with Greece being the only member to fully participate. Also, Greece hosted a new session of the Euro-Arab Dialogue four years after its stalemate. However, this temporary reactivation bore no fruits, because it was clearly associated to political considerations regarding the IsraeliPalestinian conflict.

An international conference on Palestine was held from 29 August to 7 September 1983 at the UN Office at Geneva, following previous UN General Assembly resolutions voted in 1981 and 1982. 40 Initially, the conference was to be held at the headquarters of the UNESCO in Paris. But Mitterrand was not keen to host it on French soil and was able to obtain from the PLO that the conference be held in Geneva rather than in Paris. Mitterrand was under Israeli and US pressure, but his reluctance was also a sign of a less engaged policy towards Middle Eastern affairs and of his will to avoid further social tensions, as a result of the linking of the Israeli-Palestinian conflict with the anti-Semitic terrorist attack against the Goldenberg restaurant in Paris, in August 1982. ${ }^{41}$ The Geneva declaration, issued at the end of

39 MAE, CEE 1981-1985, 5004, Copenhague COREU 3542, 22.09.1982; 3477 and 3501, 17.09.1982; 3465, 15.09.1982; 3514, 18.09.1982.

40 The relevant UNGA resolutions were the following: $36 / 120 \mathrm{C}$ of 10 December 1981, ES-7/7 of 19 August 1982 and 37/86 C of 10 December 1982. 41 J.P. FILIU, op.cit., emplacement 2636-2670. The attack against Goldenberg occurred on 9 August 1982, provoking 6 killed and 22 injured persons. It was presumably perpetrated by the Libyan-backed organization Abu Nidal. See Le Monde, 04.03.2015; for the link between anti-Semitism and the Israeli-Palestinian conflict see the interview of Pierre Mendès France in Le Nouvel Observateur, 14.08.1982. 
the conference, reflected the will to give weight to the Fez statement: a programme of action based on the Fez principles was proposed as a framework for convening a future international peace conference on the Middle East, bringing together all existing relevant UN resolutions, with a view to establish an independent Palestinian state. ${ }^{42}$

Of all the EEC countries Greece was the only one to participate as a full member at the conference, the rest of them assisting as observers. Although the Greek delegation expressed its full support to the conference's goals, it also distanced itself from all provisions that could harm its bilateral relations with Israel as incompatible with the common economic and trade policies of the EEC. Greece also defended the EEC, who was criticized as not having welcomed "all initiatives based on the recognition of the inalienable rights of the Palestinian people", essentially the Fez plan, by reminding the conference of all the relevant European declarations. Greece's full participation in the conference showed the high price Papandreou continued to put on relations with the Arab and non-aligned countries, especially at the UN. But it also highlighted the inability of Greece to influence its European partners and to fulfil a much sought after role of bridge between Europe and the Arab states.

This was further shown during the short-lived revival of the EuroArab Dialogue (EAD) in December of the same year. A combined result of the need to launch a global approach towards the Mediterranean countries and of the oil crisis of 1973, the establishment of the EAD was clearly seen from a political point of view by both sides from the beginning. For the EEC, it was part of the first attempts to develop the EPC. For the Arab League, it was also a means of de facto normalization of the PLO status in the international arena. However, the European tendency to precisely depoliticize the procedure and concentrate on the economic aspects, and the impact of the Camp David accords, led the EAD to a stalemate after $1979 .{ }^{43}$ The Lebanon War brought the subject back to the agenda as it was during the summit of Fez that the Arab states agreed to try to reactivate the EAD procedure. In November 1982, contacts were held in Tunis between the Secretary General of the Arab League and the Embassy of Denmark (the country that held the EEC presidency in the second semester of 1982). The matter was handed to the German presidency in the first semester of 1983 but the Arab side delayed the process. Given the previous eagerness of the Arab League, it is probable that the delay was due to political

42 United Nations Information System on the Question of Palestine (UNISPAL), http://unispal.un.org, Report of the International Conference on the Question of Palestine, Geneva, 29.08-07.09.1983, United Nations, New York, 1983

<http://unispal.un.org/UNISPAL.NSF/0/6F71BD16D6273ABC052565C9005730E6>. 43 G. MIGANI, La politique globale méditerranéenne de la CEE 19701972, in: A. VARSORI, G. MIGANI (eds), Europe in the International Arena During the 1970s, Peter Lang, Brussels, 2011, pp.193-210; M.E. GUASCONI, Europe and the Mediterranean in the 1970s, in: Les cahiers Irice, 1(2013), pp. 163-175. 
calculations, as Greece was the next country to take over the EEC presidency. ${ }^{44}$

Further preparation work was undertaken by the European Coordination Group at the end of spring and was intensified in September in Athens, as the Political Committee of 11-12 July had decided that the meeting of the general commission of the EAD would be held in the Greek capital. Since the first contacts taken between the EEC and the Arab League, it was clear that the political aspects would be brought up during the dialogue next to the economic and cultural ones. The question was whether these aspects would dominate the agenda. On the one hand, the European Coordination Group wanted to fix a framework in order to contain the political side of the EAD. On the other hand, the Arab proposals wanted to bring the Europeans closer to the positions of the Fez Plan or, at least, have them publicly adopt a more independent stance vis-à-vis the Reagan Plan. Clearly, the reactivation of the EAD was associated to the search for a solution to the Israeli-Palestinian conflict. However, it was out of the order of the day to fundamentally modify the European position and even the explicit reiteration of the Venice Declaration - as proposed by Greece in an effort of compromise - was excluded, in order to avoid giving the EAD the aspect of a parallel negotiation forum. ${ }^{45}$

Before the Athens European Council of 4-6 December 1983, most countries seemed to agree on the need to make a declaration on the Middle East, but no final consensus was reached. Greece proposed to revive the effort of a global approach for the Middle East by combining the Reagan and Fez plans. The UK, on the other hand, proposed a general statement of principles in order to reassure the Arab countries that Europe had actually a role to play, to define clearly the European objectives regarding Lebanon (phased withdrawal of all foreign military forces including the MNF within a given period, national reconciliation, UNIFIL action) and to provide for further diplomatic activity in accordance with the Reagan Plan. Ireland and Italy essentially agreed with the British proposals. The FRG, on the contrary, was in favour of a more reserved statement. Finally, France proposed a global European-led approach, in the spirit of the conclusions of the Solemn Declaration of the European Union of 19 June 1983 in favour of the reinforcement of the EPC, and in accordance with previous French action in the UN. ${ }^{46}$ In the end, the Athens European Council did not produce a common statement due to complete disagreement on the proposed reforms of the common agricultural policy (CAP) and to common financing mechanisms. ${ }^{47}$ Not surprisingly, it avoided any

44 MAE, CEE 1981-1985, 5009, Copenhague COREU 4739, 29.12.1982 and $4168,16.11 .1982$; Bonn COREU 741, 25.02.1983.

45 MAE, CEE 1981-1985, 5009, Bonn COREU 1901, 19.05.1983; Athens

COREU 3705, 21.09.1983 and 4208, 01.11 .1983 and 4287, 07.11.1983; Paris

COREU to all COREU, 08.02.1984; La Haye COREU, 15.05.1984.

46 HAEU [Historical Archives of the European Union], Fonds Émile Noël, Conseils européens 1975-1987, EN-1827, 04-06/12[1983], File Note: Political Cooperation: Ministerial Meeting, 22.11.1983 <http://archives.eui.eu/en/fonds/112373?item=EN.08-02-1827>. 47 AEI, The European Council [Athens Summit 1983], 04-06.12.1983. 
discussion of major international matters, something that reportedly disappointed Papandreou, who also sought a strong declaration against Turkey and the self-proclaimed Turkish Republic of the Northern Cyprus. ${ }^{48}$

Against this background, the $5^{\text {th }}$ General Commission of the EAD took place in Athens on 14 December 1983. The meeting focused on future perspectives and a possible re-launch of the dialogue, but no essential progress was made. After the discussions were concluded, the EEC presidency issued a neutral statement referring to the utility of the exchanges and the agreement of both sides about the future continuation of the dialogue. No joint statement was issued though because no common ground was found regarding the political aspects of the EAD. Further technical contacts continued throughout 1984 but the pattern remained the same, with the Arab League trying to obtain some kind of political declaration on the Middle East on behalf of the EEC and the latter avoiding it. ${ }^{49}$

Several days after the EAD meeting, Greece, Italy and France provided logistic support, under the UN flag, for the evacuation of PLO fighters from Northern Lebanon. But it was clear already, after the terrorist attacks against the French and US contingents of the MNF in Beirut in October 1983, that France had changed tactics by a more discreet, if at all, engaging in the Middle Eastern arena, not least because it failed to lead a European policy. ${ }^{50}$ France assured the EEC presidency in the first semester of 1984 and, as discussions held within the political Committee show, was utterly unfavourable to any extension of the existing European declarations. After the retreat of its forces from Lebanon in March, France preferred that any initiative regarding Lebanese-Israeli security arrangements be left to the UN. Otherwise, Mitterrand was only favourable to the designation of a factfinding mission by Italy, the country to preside the EEC in the first semester of 1985, as a sign of the EEC's willingness to help in the search of a peace solution. ${ }^{51}$ Both François Mitterrand and Bettino Craxi, the Italian Prime Minister and head of the Italian Socialist Party, toured Arab countries in November 1984 and were in close contact. Papandreou, who had also visited Jordan and Syria at the same time, joined the game during the Dublin summit of December 1984, where he asked by letter for the creation of a fact-finding mission. ${ }^{52}$ Eventually, any reference to the designation of such a mission was deleted from the final EPC texts. The common statement released after the European Council of Dublin reaffirmed the previous official positions of the EEC in a generic way and without explicitly mentioning the rights of the Palestinians to self-determination and independence.

48 Four presidencies and one memorandum, in: To Vima, 29.01.2014 <http://Www.tovima.gr/vimagazino/views/article/?aid=561685>; HAEU, Fonds Émile Noël, Conseils européens 1975-1987, EN-1827, 04-06/12[1983], Athens COREU to all COREU, CPE 4628, 30.11.1983.

49 MAE, CEE 1981-1985, 5009, Athens COREU, 09.12.1983 and

15.12.1983; Dublin COREU, 25.09.1984; Dublin COREU, 01.12.1984. 
No special role for the EEC was evoked, as had been the case in the Venice Declaration. ${ }^{53}$ As such, the Dublin statement remained within a perimeter defined by the Reagan Plan and showed that no particular European initiative was on the agenda.

This was the line followed in 1985 by the Italian presidency. The Craxi-Mitterrand correspondence shows that they both agreed on the necessity for the EEC to keep itself limited to the exchange of views between its members within the framework of the EPC and to encourage a common Jordanian-Palestinian approach that was in progress after the meeting of the Palestine National Council in Amman in November 1984. ${ }^{54}$ Following the Jordanian-Palestinian agreement of February 1985, the EPC meeting of 29 April 1985 in Luxembourg led to a statement expressing satisfaction and reaffirming that the EEC was willing to contribute to such a process on the basis of the principles previously expressed in the EEC statements regarding the right of all states to exist, Israel included, and the need to associate the PLO in any negotiations. In this context, Greece was too small a player to play a leading role, though the country followed closely all the relevant European activities in the Middle East countries which in any case had considerably slowed down. ${ }^{55}$

\section{The rise of the Greek-Libyan Connection, 1981- 1984}

Andreas Papandreou met Muammar Gaddafi for the first time in 1975 in Tripoli. ${ }^{56}$ He was encouraged to develop contacts with Libya by Vassos Lyssaridis, the leader of the Cypriot Labour Party (EDEK) and even Archbishop Michail Makarios, the President of the Republic of Cyprus. Members of the PASOK executive committee, such as Manos Kafetzopoulos, later Ambassador in Tripoli, Akis Tsohatzopoulos, who served as Minister in several PASOK governments from 1981 to 2004, and Phaedon Metallinos, who later served in the Embassies of Paris and Luxembourg, visited Tripoli in 1976 and 1977. ${ }^{57}$ An association of Greek-Libyan

53 HAEU, Fonds Émile Noël, Conseils européens 1975-1987, EN-1877, Note de dossier: session du Conseil européen Dublin 3-4 décembre 1984, $06.12 .1984<$ http://archives.eui.eu/en/fonds/112394?item=EN.08-02-1877>; Margaret Thatcher Foundation, EC, Dublin European Council (Presidency Conclusions) <http://www.margaretthatcher.org/document/114155>. 54 MAE, CEE 1981-1985, 5009, Dublin COREU, 21.12.1984; 13/EU, Mitterrand to Craxi, 11.01.1985.

55 Communiqué commun des ministres des affaires étrangères de la CEE en date du 29 avril 1985 sur le Moyen Orient, l'Afrique Australe, le Soudan, l'UNESCO et la réunion d'Ottawa sur les Droits de l'Homme, 1985 <http://discours.vie-publique.fr/notices/852006000.html>; MAE, CEE 19811985, 5004, Damas 265, 06.04.1985. 56 Andreas Papandreou Foundation Online Archive, <http://agp.archeio.gr/ap.php?page=ap_cv\&lang=en>.

57 Interview of Manos Kafetzopoulos to the author [hereafter: Kafetzopoulos to author], 21.12.2011. Manos Kafetzopoulos, a former militant of PAK-London, was member of the executive committee of the Pasok, in charge of foreign relations, and Ambassador in Libya from 1981 to 1986. 
friendship was founded in 1978 by PASOK youths of the Trotskyist stream of the party. These contacts were further developed in the framework of the conferences of the Southern European and Mediterranean socialist and progressive parties from 1976 onwards. From a certain point of view, encouraged as they were by the Cypriots, Papandreou's contacts with Libya continued a tradition of relations with the non-alignment movement that Archbishop Makarios had established as a means of protection against Turkey, now placed at the level of a regional EuroMediterranean network where the Greek Socialists tried to gain influence and in which neither Turkish nor Israeli political formations participated. Libya was the party's privileged interlocutor in North Africa. The country seemed attractive at the time because of its socialist-inspired economic model but these perceptions were to change after 1981 when the Libyans would be severely judged as unreliable economic partners. Post-"Arab Spring" perceptions make past contacts with Arab dictators appear, to say the very least, as sins of youth for the European leaders. However, such contacts were also part of a larger Euro-Mediterranean network in which many European Socialists, who would come to power in the eighties and would later be present at the launch of the Barcelona Process in 1995, participated. ${ }^{58}$

To Libya, the network of the Mediterranean socialist parties represented a certain domain of international activity. Marginalised in the inter-Arab scene, out of rivalry with Egypt and Syria, and on bad terms with the US, Gaddafi's alternatives consisted in developing careful relations with the USSR and being active in three international domains: the Mediterranean region, Africa and the Israeli-Palestinian conflict, where he mainly backed dissident Palestinian formations that opposed Arafat, essentially the Abu Nidal Organization. ${ }^{59}$ From this point of view, Papandreou's election in 1981 provided Gaddafi with a much needed potential connexion to the EEC, other than the important bilateral economic ties he held mainly with Germany, Italy and France. ${ }^{60}$ Manos Kafetzopoulos, who was not a diplomat but a party member, was appointed Ambassador in Tripoli. This was a sign of the importance Papandreou attached to the Greek-Libyan relationship. But it also highlighted his distrust of the Greek diplomatic corps that often served independently of the regime's change after 1974, as the previous Greek Ambassador in Libya had been appointed by the Colonels' Junta. ${ }^{61}$

From 1986 on, he served in the Foreign Ministry as Adviser for Arab and Mediterranean affairs.

58 Anonymous interview to the author, 22.12.2011; interview of Theodoros Pangalos to the author, 19.12.2011. See also A. SCEBERRAS TRIGONA, 40 Years of Malta Libya Relations - a Brief Overview, PL International Secretary, 2009

<http://plinternationalsecretary.blogspot.com/2009/09/highlights-of-40years-of-malta-libya.html>.

59 Y. RONEN, Qaddafi's Libya in World Politics, Lynne Rienner Publishers, Boulder (Colorado), 2008, pp.11-12 and 16-18.

60 Y. ZOUBIR, Les États-Unis, l'Europe et la libye : de la réhabilitation de Kadhafi à son renversement, in: L'Année du Maghreb, 2012, <http://anneemaghreb.revues.org/1551>.

61 On this and the main structural aspects of Papandreou's foreign policy see J.O. IATRIDES, Papandreou's Foreign Policy, in: T.C. KARIOTIS 
Kafetzopoulos was acquainted with Ahmad Shahati, chief of the Libyan Foreign Affairs office, in the seventies, in the framework of the Mediterranean socialist conferences, but also with the Fatah section that was based in Tripoli, which made him a well-recognized actor in the bilateral relation between Tripoli and Athens. As Ambassador, he had liberty in his initiatives and direct communication with Papandreou. ${ }^{62}$

Right after Papandreou's election, Colonel Gaddafi seemed eager to visit Athens but the idea was entirely opposed by the Greek President Karamanlis, who was cautious to preserve Greece's relations with the USA. According to Kafetzopoulos, Papandreou was not willing to harm his relations with Karamanlis over this. So, perhaps conveniently, Gaddafi's visit in Athens was soon off the agenda. Greek-Libyan economic relations paid the price, as oil exports to Greece and payments to construction companies active in Libya (a total of 120 million dollars) ceased. However, things had returned to normal by June 1982. ${ }^{63}$ It is not clear what made Gaddafi change his attitude, but this was probably due to Greece's activity over the Lebanon War and its links to France. Greece seemed then potentially useful in two domains that were crucial to Libya, the Israeli-Palestinian conflict and Africa. Gaddafi had every reason to be on good terms with Papandreou, especially since the latter was not an enemy for him. The French-Libyan relations were strained at the time because of Libya's support to the opponents of the legal government of Chad that was backed by France. According to former Foreign Minister of France, Roland Dumas, Andreas Papandreou was one of the intermediaries Gaddafi used during this period to declare himself disposed to come to terms with the French regarding Chad, the other one being Bruno Kreisky. For Greece, except for their economic aspects, the importance of relations with Libya and the Arab countries in general - was further underlined after the proclamation of the Turkish Republic of Northern Cyprus (TRNC) on 15 November 1983 and its search for international recognition. In accordance with the UN Security Council Resolution 541, the Arab states declared themselves to be opposed to the self-proclamation of the TRNC and did not grant it diplomatic recognition nor upgraded the observer status the Cypriot-Turkish community held in the Organization of the Islamic Conference to full membership. ${ }^{64}$

It was against this background that a meeting between Papandreou and Gaddafi came back on the agenda in 1984. The issue reportedly raised a big debate within governmental circles. Foreign Minister Yannos Haralambopoulos, Under-Secretary of State for Foreign Affairs in charge of the Mediterranean and Arab Affairs, Carolos Papoulias, ViceMinister of Economy Costis Vaitsos and Ambassador to Tripoli Kafetzopoulos between those who were convinced about the usefulness of

(ed.), The Greek Socialist Experiment. Papandreou's Greece 1981-1989, Pella, New York, 1992, pp.127-160.

62 Kafetzopoulos to author; Le Monde, 16.11.1984.

63 To Pontiki, 10.08 .1984$.

64 R. DUMAS, Affaires étrangères..., op.cit., p.312; J.O. IATRIDES, op.cit., p.137. 
such a meeting and those concerned not to harm Greek-US relations. Once more, President Karamanlis objected to hosting Gaddafi in Athens. ${ }^{65}$ On Gaddafi's invitation, it was finally Andreas Papandreou who visited Tripoli on 23-24 September 1984. The press reported at the time the signing of a bilateral economic accord that provided for cooperation in the investment banking sector, technology transfers, infrastructure construction, and commercial relations of a total value of 1 billion dollars. Several years later, the accord was still not fully implemented, in part because of the reluctance of Greek companies to develop further activities in Libya. ${ }^{66}$ Moreover, a 75 million dollars contract regarding imports to Libya of anti-aircraft weapons made by the Greek Armament Industry did not go further because of US pressure put on Greece and Libya's backing of terrorist activities. Since its sudden announcement in mid-September, however, Papandreou's visit was mostly associated to a probable Greek mediation in Chad. France and Libya had agreed to mutually withdraw their military forces from this country following the mediation of Chancellor Kreisky on 15 september. But Gaddafi was not only interested in coming to terms with the French. He also wanted to do it in an official way by publicly meeting Mitterrand. ${ }^{67}$ According to one source, it was the Ambassador of Yugoslavia in Tripoli who did the matchmaker between Greeks and Libyans by encouraging the former to propose Papandreou's services to Gaddafi. ${ }^{68}$ So, Papandreou's visit conveniently combined international activity with bilateral economic arrangements, but also with domestic concerns: after the congress of the PASOK (May 1984) he needed to show that the party had not lost its third road soul; and, following the European elections of June, that saw the party's electoral force diminished, he also needed to boost his voters. ${ }^{69}$

The meeting between Mitterrand and Gaddafi took place at Elounda, Crete, on 15 November 1984. Elounda was a convenient choice, as neither Mitterrand nor Karamanlis wished to have Gaddafi officially invited in their respective capitals. There is no official account of the meeting, but according to the Greek and French press the negotiations were lengthy and laborious. ${ }^{70}$ The Libyan forces were still in Chad, whereas the French had already ordered the retreat of theirs (operation Manta) before the agreed deadline, which was precisely the 15 November. The French had been publicly humiliated by US revelations on the Libyan inconsistency just days after a joint communiqué had simultaneously been released by the French and the Libyan Foreign Ministries. The Chad

65 To Pontiki, 28.09.1984.

66 To Vima, 25.09.1984. See also M. XANTHAKIS, P. ALEXAKIS, C. CHRistopoulos, The Arab Countries. A Survey of Their Economies and Relations with Greece, Foundation for Mediterranean Studies, Athens, 1989, pp.137 and 143 .

67 To Vima, 19.09.1984 and 20.09.1984; R. DUMAS, Affaires étrangères..., op.cit., pp.312-313; R. DUMAS, Tchad: histoire secrète d'une négociation, in: La lettre de l'Institut François Mitterrand, 12.06.2005 <http://www.mitterrand.org/Tchad-histoire-secrete-d-une.html>. $68 \quad$ Kafetzopoulos to author.

69 To Pontiki, 29.12.1984, pp.6-7.

70 R. DUMAS, Tchad..., op.cit.; Ethnos, 16.11.1984; Le Monde, 16.11.1984 and 17.11.1984. 
affair did not find a solution until two years later, but, at the time, Andreas Papandreou was able to reinforce his image as a promoter of peace in the Mediterranean and as a mediator between the West and Gaddafi, as he had previously obtained the release of French (1983) and British (1984) nationals that were detained in Libya. The Elounda meeting also coincided with the decision of the Greek government to buy 40 French Dassault Mirage 2000 fighter aircraft, as part of the Greek air forces' modernization programme, decreasing by half an initial order that provided for the purchase of $80 \mathrm{~F}-16 \mathrm{~s}$ from the USA. ${ }^{71}$

\section{The dissolution of the Greek-Libyan connexion, $1985-1986$}

The foundations of the Greek-Libyan relationship were fragile and this soon became plainly evident. In 1985, the Reagan administration adopted a tougher stance towards international terrorism emanating from the Middle East. ${ }^{72}$ In Greece, Karamanlis, whom the US trusted, was no longer President, after Papandreou backed Christos Sartzetakis in the presidential election of March 1985. As a consequence, direct US pressure on the Greek government regarding its relations with Gaddafi became stronger. For example, Washington made use of the threat to cancel the delivery of the 40 F-16 aircraft, something that would affect the military balance between Greece and Turkey. In June, following the hi-jack of the TWA 847 Athens to Rome flight by two members of Hezbollah, the state Department issued an instruction against travel via Athens airport. The warning stayed valid for only a month but it was effective, as companies such as Pan-American Airways went so far as to temporarily suspend all flights to and from Athens. ${ }^{73}$

Libyan-backed terrorist activities had indeed become a problem for Greece by 1985 (see graphic). According to data available by the RAND Database of Worldwide Terrorism Incidents (RDWTI) on incidents related to Middle East-related terrorism in Greece, out of 20 incidents occurring between 1981 and 1988, a peak was noted in 1985. ${ }^{74}$ The year saw 9 incidents, of which 7 were linked to Libya (Black September, Abu Nidal). The Greek government had suppressed the 1978 anti-terrorist law in 1983 and although it did not pass a new one, the Greek authorities plainly cooperated with the USA and benefited from the training and

71 Le Monde, 16.11.1984 and 17.11.1984; C. ESTIER, France-Libye: les dessous d'une affaire complexe, in: L'Unité, 23.11.1984. See also To Pontiki, 23.11.1984, pp.6-7.

72 M. TOALDO, The Reagan Administration and the Origins of the War on Terror: Lebanon and Libya as case studies, in: New Middle Eastern Studies, 2(2012) <http://www.brismes.ac.uk/nmes/archives/767>. 73 Kafetzopoulos to author. See also LA Times, 22.07.1985; Chicago Tribune, 20.06 .1985 .

$74<$ http://smapp.rand.org/rwtid/search_form.php>. Selected search values: 1968-2010, Greece, international incident (true), attack claimed (true). 214 records found from 1971 to 2009. Records on incidents linked to Middle Eastern terrorism were then manually retrieved and crossed with further bibliography, mainly SEALE 1992. 
equipment they were given. By April 1986, the security of Athens airport had considerably improved. ${ }^{75}$ At the same time, relations with Libya took a different turn: by March 1986, the decision was taken to replace Kafetzopoulos, who would join the Ministry of Foreign Affairs as advisor for Arab Affairs, with Vanghelis Hatzimanolis, an economist and member of PASOK's committee of foreign relations. ${ }^{76}$ The aim was to push for implementation of the 1984 accords and apparently Greece attached more importance to the development of the economic aspects of its relations with Libya. Undoubtedly, these were also signs that the Greek government was careful to preserve its relations with the USA.

\section{Network visualization of the main terrorist organizations that perpetrated attacks in Greece from 1981 to 1988 and the countries the attacks were related to}

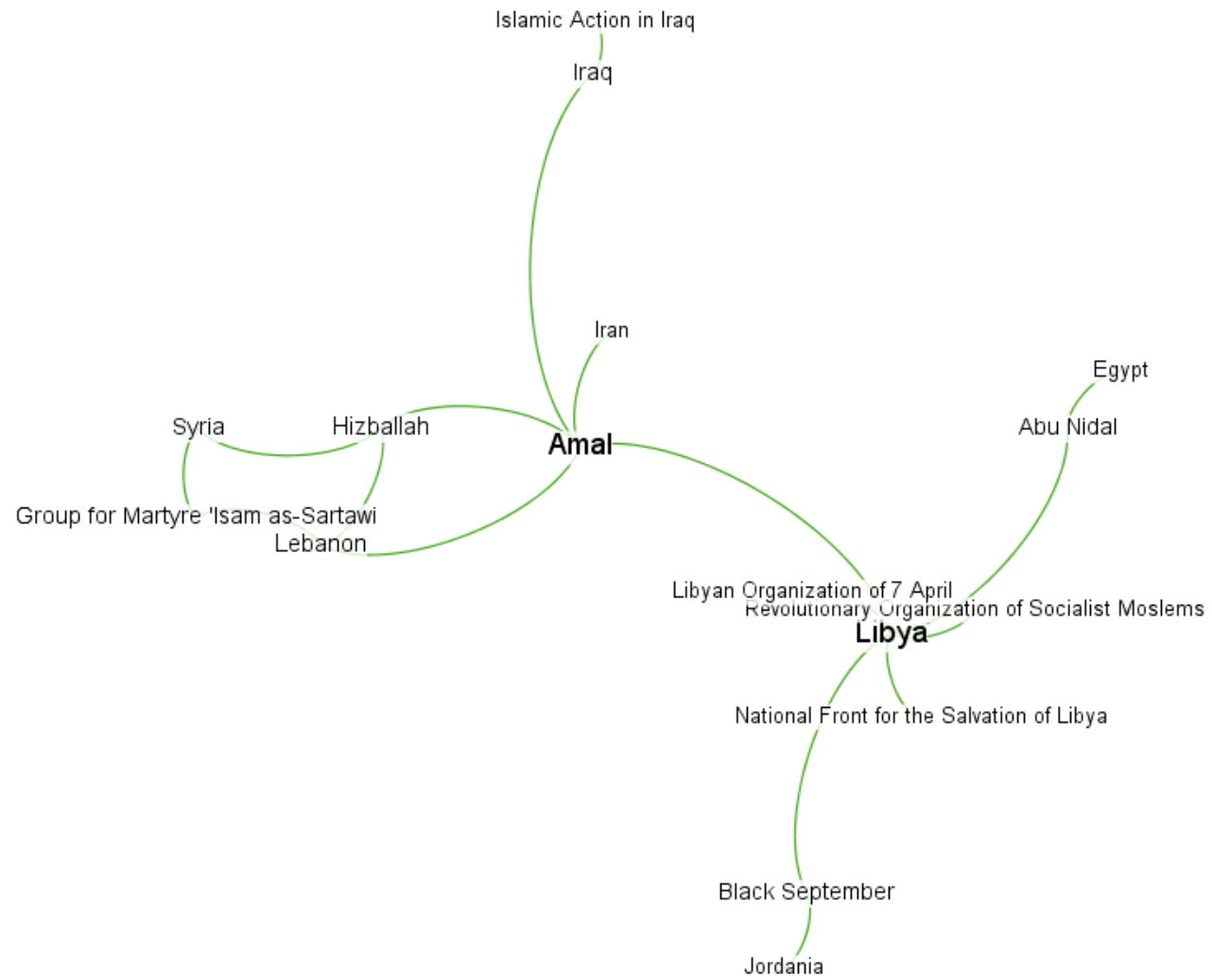

(Source of data: RAND Database of Worldwide Terrorism Incidents. Visualization software: Gephi) 
In 1986, Greek-Libyan relations were further depoliticized under the influence of the crisis between Gaddafi and the USA and the readjustment of Greek-US relations. In late March, tension between the Libyans and the Americans during a US naval exercise in the Gulf of Sidra escalated to limited military actions. At the time, Secretary of State George Shultz was in Athens (25-27 March) for discussions on the future of the US bases in Greece and Greek-US relations, with Libya also being part of the agenda. Official Greek reaction to the events was cautious and balanced and showed no support for Libyan claims in the Gulf of Sidra. The US operation was condemned by the PASOK's committee for foreign relations, but the party abstained from the antiUS demonstrations that were organized in the Greek capital. ${ }^{77}$

The terrorist attack on the discotheque "La Belle" in West Berlin, on 6 April, for which the US - rightly, as was later proved - blamed Gaddafi, led to the launch of a series of US air strikes against Libya. The EEC countries, with the exception of the UK, did not allow to use their military bases in the operation against Libya. Under US pressure, they denounced Libyan involvement in terrorism and agreed to restrict freedom of movement for the country's diplomatic staff in European capitals, but did not take any economic measures against Tripoli. ${ }^{78}$ In a speech in the Greek Parliament, Papandreou criticized the US action but, in general, Greece's attitude was along the same lines as that of all the EEC countries without trying to go it alone. The normalization of the Greek government's attitude was best shown when Greece received an unexpected - and probably unwelcome - visit of a Libyan envoy shortly after the beginning of the US bombings. Ahmad Shahati, head of the Libyan Foreign Affairs office and an old acquaintance of the Greek socialists, landed to Athens on 17 April, where he held talks with Foreign Minister Papoulias and Papandreou. According to the official declaration of the government, Gaddafi hoped for an EEC initiative in favour of peace in the Mediterranean. But, Papandreou said, the Libyan demand did not mean that Greece would act and, if it was the case, this would only be in a European framework. Papandreou also condemned terrorism and tension in the Mediterranean. Shahati left Athens only to return again in the same evening under circumstances that remain unclear. He convoked a press conference around midnight, where he denied that Gaddafi had asked for the mediation of the EEC. The conference was brutally interrupted by Greek Police officials and Shahati was evacuated. ${ }^{79}$ After this inglorious incident, much speculation was made about the content of the message of Gaddafi. According to Manos Kafetzopoulos, the Libyan leader had asked for the active support of Papandreou against the US operations. This meant various kinds of support: diplomatic, through an EEC action;

77 Ronald Reagan Presidential Library, Statement by Principal Deputy Press Secretary Speakes on the Gulf of Sidra Incident, 24.03.1986, <http://www.reagan.utexas.edu/archives/speeches/1986/32486b.htm>. See also To Vima, 30.03.1986. p.25.

$78 \quad$ New York Times, 13.11.2001

<http://www.nytimes.com/2001/11/14/world/4-guilty-in-fatal-1986-berlindisco-bombing-linked-to-libya.html> and The Guardian, 15.04.1986.

79 To Vima, 20 and 27.04.1986 and Ethnos, 18, 19 and 20.04.1986. 
humanitarian, by hosting Libyan children in Greece, including Gaddafi's children; and even military, by totally forbidding the use of the US bases in Greece even for interception purposes. ${ }^{80}$ Gaddafi himself confirmed several years later that he had considered launching missile attacks against the US bases on Crete. The fact was that the April USLibyan crisis revealed a total change in the Greek government's attitude towards Gaddafi. In July 1986, following the EEC decisions and a Greek-Libyan agreement, the Libyan Popular Office of Athens reduced its staff. ${ }^{81}$

\section{Conclusion}

Greece's attitude towards the Israeli-Palestinian conflict in the framework of the EPC from 1981 to 1985 was a conjunction of Realpolitik concerns, ideology and even emotional attachment to the Palestinian cause. Indeed, relevant Greek action in the EEC offers an interesting insight to the connections between foreign policy and emotional attitudes inspired by a nation's own history, collective memory and even nationalism. In particular, different European attitudes during the 1982 Lebanon War show that emotions can be a driving force in rational decision making on foreign affairs matters when Realpolitik concerns and the balance of power in a collective framework, in this case the EPC, allow it. ${ }^{82}$ Greece's energy also shows that the country was quick to adapt to the EEC foreign-policy making mechanisms and to contribute to decision-making through collaboration with its partners soon after fully joining the Community. Greece was able to profit from European attitudes when these fitted its general goals and appear as a positive and effective player in the Mediterranean. However, there were limits and they became evident when bigger players that led the game France or Italy - did not leave Greece enough space or, indeed, when Greek positions were out of time.

The case of Libya, on the other hand, shows a quick Westernisation of Greece's policy towards this country under the combined influence of three factors: US pressure on Greece, Libyan backed terrorism and the liberalisation of European and third world economies that favoured developing economic rather than political relations with Libya. In 1986, from all aspects, Greece's attitude was entirely part of a multilateral EEC approach towards the US-Libyan crisis, formalised or not, and was even claimed as such. The personal policy that Papandreou had followed up until then, in part out of domestic concerns and in

80

81

To Pontiki, 25.04.1986, pp.6-7.

New York Times, 08.05.1990,

<http://www. nytimes.com/1990/05/08/world/qaddafi-tells-of-plan-to-attackus-bases.html>; To Pontiki, 11.07.1986.

82 For the case of Ireland see R. MILLER, Ireland and the Palestine Question..., op.cit.; R. MILLER, Why the Irish Support Palestine, in: Foreign Policy, 24.06.2010, <http://foreignpolicy.com/2010/06/24/whythe-irish-support-palestine/>; for the case of Germany see A.-K. KREFT, op.cit., pp.60-63. 
part because of the nature of the relations one could have with Gaddafi, who totally dominated the exercise of Libyan foreign policy, seemed completely outdated once terrorism entered the agenda of international relations. The Papandreou-Gaddafi relationship reveals an interesting aspect of socialisation between Mediterranean leaders that developed also in the name of an updated third-worldism during the Second Cold War, only to vanish under the impact of the different evolution the Mediterranean North and South and the coming dissolution of the bipolar world.

Last but not least, the shadow of the Cyprus affair and the GreekTurkish relations, that one finds constantly behind Greece's Arab policy and PASOK's third road approach, would in their turn be Europeanised, in the sense of a more denationalised and multilateral approach, with the adoption of a positive Greek attitude towards Turkey's EU candidature at the 1999 Helsinki Council and Cyprus's accession to the EU in 2004.83 These policies were principally led or backed by post-Papandreou socialist governments. However, the reorientation towards a European option for Cyprus appeared already on the horizon in the mid-eighties, as the dissolution of Cold War balances was coming into the picture, rendering its foreign policy's third world orientations outdated. ${ }^{84}$

In conclusion, Papandreou's tentative of exercising a multidimensional foreign policy during this period shows how fluid a concept the Mediterranean eventually remained when faced with Realpolitik and domestic concerns, continuous conflict and lack of a common European foreign policy. 